\title{
Consumption of macroinvertebrates by invasive and native gammarids: a comparison
}

\author{
Holger KRISP and Gerhard MAIER ${ }^{1) *}$ \\ Department of Experimental Ecology of Animals, University of Ulm, Albert-Einstein-Allee 11, 89069 Ulm, Germany \\ ${ }^{1)}$ Department of Biology III, University of Ulm, Albert-Einstein-Allee 11, 89069 Ulm, Germany \\ *e-mail corresponding author: gerhard.maier@biologie.uni-ulm.de
}

\begin{abstract}
The Ponto-Caspian gammarids Dikerogammarus villosus SOVINSKIJ and Echinogammarus ischnus STEBBING have invaded Central-European streams in the early 1990s. Declines in macroinvertebrates have been observed since the arrival of invasive species. To elucidate the predatory impact of gammarids on the macroinvertebrate community, we conducted laboratory experiments with macroinvertebrate prey taxa and native and invasive gammarids as predators. Dikerogammarus villosus, which is known to be a strong predator, consumed more and a broader range of prey than $\mathrm{E}$. ischnus or the native gammarids, Gammarus pulex L. and Gammarus roeseli GERVAIS. Echinogammarus ischnus consumed a somewhat higher amount of prey organisms than G. pulex and a higher number and a broader range than G. roeseli. Adult D. villosus consumed up to $25 \mathrm{mg}$ macroinvertebrate biomass (wet weight) per day which corresponds to approximately 1/3 of their own biomass. Chironomid larvae were preferred by all gammarids tested. Taking into account that gammarids density may surpass 1000 ind $\mathrm{m}^{-2}$, our results suggest that the predatory behaviour of invasive gammarids, in particular of $\mathrm{D}$. villosus, may have contributed to the decline of some macroinvertebrate taxa in some European streams.
\end{abstract}

Key words: gammarids, invasive species, predation, macrozoobenthos

\section{INTRODUCTION}

The invasion of freshwater ecosystems by nonindigenous species has increased dramatically in the last century as a result of shipping and building of canals which connect large rivers (e.g. Kinzelbach 1995; Tittizer 1996). For example, in Germany, the opening of the Main-Danube canal in 1992 led to an invasion of numerous species from the Ponto-Caspian region into the rivers Main and Rhine (e.g. Tittizer 1996; Tittizer et al. 2000). Invaders frequently interfere with native species causing shifts in species composition and abundance (e.g. Dick 1996; van der Velde 2000).

Among invasives, the Ponto-Caspian crustacean Dikerogammarus villosus SOVINSKIJ, a member of amphipods, has become one of the most abundant species in the rivers Main, Rhine and Danube (Kley \& Maier 2003). This species is known to be an efficient predator which has replaced native and invasive gammarids in many communities (Dick \& Platvoet 2000; Kinzler \& Maier 2003). Considerable declines in the whole macroinvertebrate fauna along with the arrival of $D$. villosus have been reported from waters in the Netherlands (Dick \& Platvoet 2000; van der Velde et al. 2000; Dick et al. 2002) and France (Devin et al. 2001). Recently, Dick et al. (2002) showed in laboratory experiments that $D$. villosus killed more macroinvertebrates than did Gammarus duebeni LILLJEBORG, a species native and widespread in western Europe (Dick \& Platvoet 2000). In the rivers Rhine, Main and Danube,
D. villosus frequently coexists with another invasive gammarid, Echinogammarus ischnus STEBBING, native to the Ponto-Caspian region (Kley \& Maier 2003). To assess the predatory impact of invasives on macroinvertebrates we performed a series of laboratory experiments with mixed and single macroinvertebrate prey taxa and gammarids as predators. We compared the predatory impact of D. villosus and E. ischnus on macroinvertebrates with that of two native species (Gammarus pulex L. and Gammarus roeseli GERVAIS) which were the dominant gammarids in the Main, Danube and Rhine systems until the late 1980s. We expected that D. villosus and E. ischnus are much stronger predators than are native species, consuming more and a broader spectrum of macroinvertebrates.

\section{METHODS}

\subsection{Collection and maintenance}

Invasive gammarids (D. villosus and E. ischnus) were collected by kick and pond net sampling at the lower reaches of the River Danube near the town Deggendorf; native gammarids ( $G$. pulex and $G$. roeseli) were obtained with the same sampling method from the upper reaches of the same river near the town of Ulm. Prior to experiments, gammarids were separated by species and maintained under standardized conditions (17-18 ${ }^{\circ} \mathrm{C}$; artificial light provided by Osram L36 W/25 universal white lamps, light intensity at water surface 5 $\mathrm{W} \mathrm{m}^{-2}$, light cycle $16 \mathrm{~L}: 8 \mathrm{D}$ ) in aerated plastic vessels $(35 \times 25 \times 15 \mathrm{~cm})$ which contained $8-9$ L of aged tap 
Tab. 1. Summary of predator-prey experiments. To estimate biomass consumed predator ${ }^{-1}$ day $^{-1}$, fresh-weights are given in parentheses for those prey which were employed in experiment 3.

\begin{tabular}{|c|c|c|c|c|c|}
\hline Exp. no. & Type & Predators & Prey Organisms & $\begin{array}{l}\text { Prey length }(\mathrm{mm}) \\
\text { (exp. } 3 \text { weight in } \mathrm{mg})\end{array}$ & $\begin{array}{l}\text { Replicate trials } \\
\text { with controls }\end{array}$ \\
\hline 1 & single prey & $\begin{array}{l}\text { D. villosus } \\
\text { E. ischnus } \\
\text { G. pulex } \\
\text { G. roeseli }\end{array}$ & $\begin{array}{c}\text { Dugesia lugubris } \\
\text { Glossifonia heteroclita } \\
\text { Tubifex sp. } \\
\text { Asellus aquaticus } \\
\text { Chironomid larva } \\
\text { Simuliid larva } \\
\text { Ephemerella } \text { sp. larva } \\
\text { Calopteryx splendens larva } \\
\text { Hydropsyche sp. larva } \\
\text { Potamophylax sp. larva } \\
\text { Corixa } \mathrm{sp} .\end{array}$ & $\begin{array}{c}5-8 \\
10-15 \\
20 \\
6-8 \\
10 \\
3 \\
10 \\
25 \\
10 \\
15 \\
10\end{array}$ & 264 \\
\hline 2 & mixed prey & $\begin{array}{l}\text { D. villosus } \\
\text { E. ischnus } \\
\text { G. pulex } \\
\text { G. roeseli }\end{array}$ & $\begin{array}{c}\text { A. aquaticus, chironomid larva, siimulid } \\
\text { larva, Ephemerella sp. larva } \\
\text { Hydropsyche sp. larva } \\
\text { A. aquaticus, chironomid larva }\end{array}$ & $\begin{array}{c}6-8,10,3 \\
10 \\
10 \\
6-8(4.1), 10(3.6)\end{array}$ & $\begin{array}{l}32 \\
200\end{array}$ \\
\hline 3 & single prey & $\begin{array}{l}\text { D. villosus } \\
\text { G. roeseli }\end{array}$ & & & \\
\hline
\end{tabular}

water (water height $8 \mathrm{~cm}$; pH 7-8; conductivity $500 \mu \mathrm{S}$ $\mathrm{cm}^{-1}$, total hardness $\left.13.2 \mathrm{dH}\right)$. Substrates from the natural habitat (gravel: $3-10 \mathrm{~cm}$ grain size, stones: $4-10$ $\mathrm{cm}$ diameter) and 3-4 stems of the aquatic plant Fontinalis antipyretica L. were introduced into the vessels to provide shelter for gammarids. Leaves of willow (Salix alba L.), ash (Fraxinus excelsior L.) and elm (Ulmus carpinifolia GLEDITSCH) which were collected at the shores of the River Danube, dried and treated as described in Callies (1996) served as food. Gammarid density in the vessels was approximately 1000 ind $\mathrm{m}^{-2}$ which is within the range of gammarid density observed at the collection sites (e.g. Kley \& Maier 2003). Under these conditions gammarids could be maintained for weeks.

All experiments were run under the same temperature and light regime as employed during maintenance of gammarids. A gentle water movement provided by air stones was used in the experiments, consistent with field observations that showed current velocity at the shores of the river is very low $\left(<0.02 \mathrm{~m} \mathrm{~s}^{-1}\right)$. Prey organisms (cf. Tab. 1) were collected in the Danube at the site near Ulm approximately $2 \mathrm{~h}$ before they were used in an experiment. Water temperature at the collection date was similar to the temperature during experiments (approximately $18{ }^{\circ} \mathrm{C}$ ). All substrate was washed repeatedly before it was used in an experiment to remove meiofauna.

\subsection{Predator-prey experiments}

In the first predator-prey experiment, which simply served to evaluate the range of gammarids diets, 5 individuals of a macroinvertebrate species were introduced into a plastic aquarium $(35 \times 25 \times 17 \mathrm{~cm})$ supplied with gravel and stones (grain size: $3-10 \mathrm{~cm}$ ) as substratum. Prey was allowed to settle for 1-2 $\mathrm{h}$ before predators $(5$ gammarids) were added. Eleven prey organisms from different taxonomic groups were tested (Tab. 1). These prey organisms were important components of the natural community at the Danube near Ulm. Three replicate trials for each prey-predator combination and three controls (without gammarids) were run. Only adult gammarids of the same size (approximately $20 \mathrm{~mm}$ ) and of mixed sex (50\% males and 50\% females) were used and allowed to feed on prey for $24 \mathrm{~h}$. Gammarids of mixed sex were used, reflective of mixed-sex populations in the nature. Predation rates were estimated as difference in macroinvertebrate survival between aquaria with gammarids and controls. Cannibalism between gammarids was not observed during the experimental period.

In the second predator-prey experiment to evaluate prey preference, combinations of prey species (5 individuals of those species which were consumed in the first experiment) were offered to one adult specimen $(15-20 \mathrm{~mm})$ of either D. villosus, E. ischnus, G. pulex or $G$. roeseli in $35 \times 25 \times 17 \mathrm{~cm}$ aquaria supplied with gravel and stone substrate (grain size $3-10 \mathrm{~cm}$ ). Prey was allowed to settle for 1-2 $\mathrm{h}$ before gammarids were introduced. One set of experiments was run without gammarids as a control to assess interactions between prey species. Four experiments for each gammarid/prey combination and 4 control experiments were run. Difference in prey survival between control and experimental aquaria was estimated after $24 \mathrm{~h}$.

In the third predator-prey experiment to estimate maximum gammarid predation rates, one specimen of either D. villosus, E. ischnus, G. pulex or G. roeseli was combined with abundant quantities (10 prey per $12 \times 12$ $\times 6 \mathrm{~cm}$ aquarium which corresponds to a density of 694 $\mathrm{m}^{-2}$ ) of either a mobile prey (A. aquaticus L.) or a less mobile prey (chironomid larvae). Experiments without gammarids were conducted to control for interactions between prey. Aquaria were provided with filter tubes 


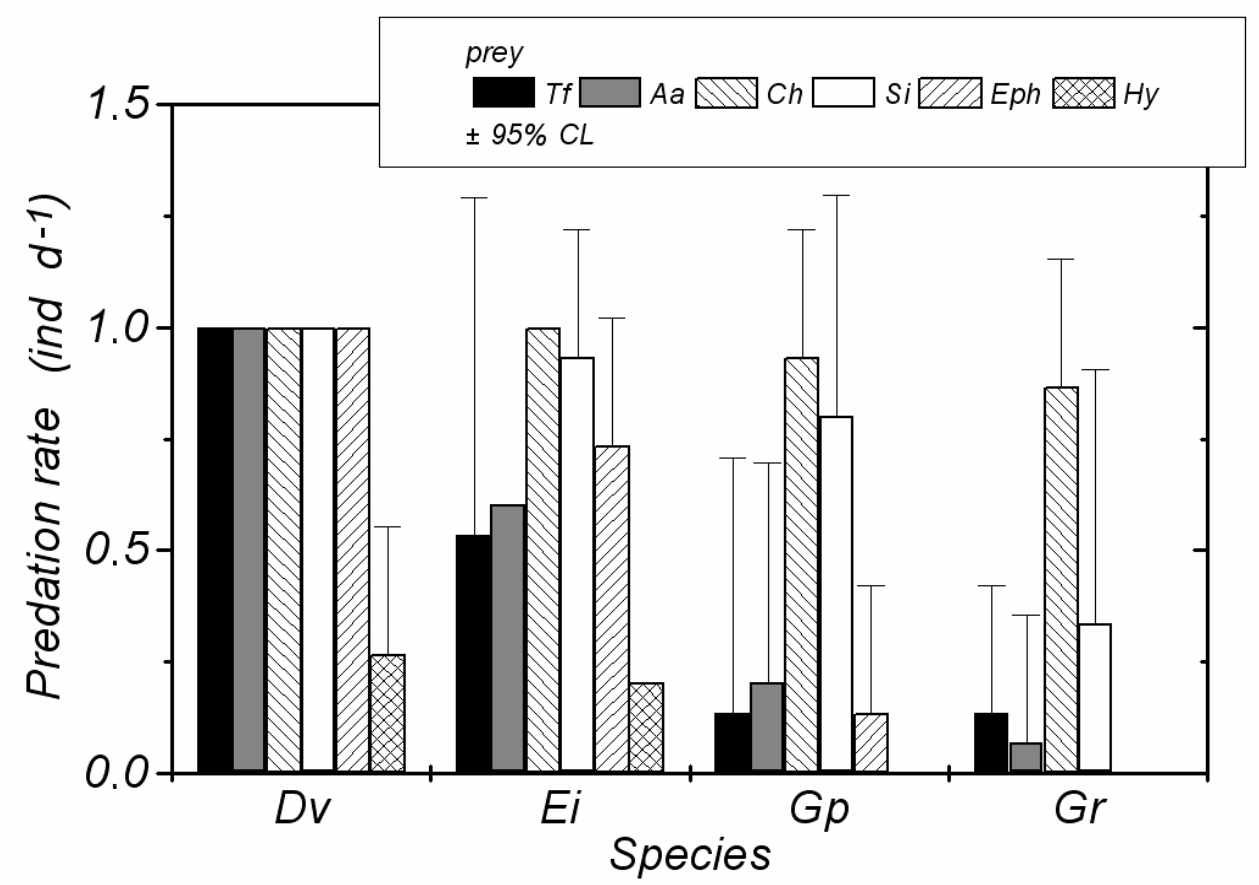

Fig. 1. Average number of macroinvertebrates $( \pm 95 \% \mathrm{CL})$ consumed by one adult invasive $(\mathrm{Dv}=$ Dikerogammarus villosus; Ei $=$ Echinogammarus ischnus $)$ and native $(\mathrm{Gp}=$ Gammarus pulex; $\mathrm{Gr}=$ Gammarus roeseli $)$ gammarid during $24 \mathrm{~h}$ in single prey experiments. Prey: $\mathrm{Tf}=$ Tubifex sp.; $\mathrm{Aa}=$ Asellus aquaticus; $\mathrm{Ch}=$ chironomid larvae; $\mathrm{Si}=$ simuliid larvae; Eph $=$ larvae of Ephemerella sp.; Hy = larvae of Hydropsyche sp.

(1 cm long, $0.5 \mathrm{~cm}$ tube hole; cf. Dick 1992; Kinzler \& Maier 2003) as substratum. One hundred replicate experiments (10 with A. aquaticus and 15 with chironomid larvae and each gammarid species) and 100 control experiments were performed. Predation rate was assessed as difference beween prey number in controls and experimental aquaria at the end of an experiment (after $24 \mathrm{~h}$ ). To estimate biomass consumed per gammarid and day, prey were weighed with a Sartorius 2004 MP balance; weights were multipled with the number of prey consumed.

A series of Kruskal-Wallis ANOVAs and one-way ANOVAs, dependent on whether data were normally distributed or not, followed by U-test or Tukey's post $h o c$ test for pairwise comparison were employed to estimate whether consumption rates varied with gammarid and / or prey species.

\section{RESULTS}

In the first single-prey experiment, gammarids consumed 4-6 of 11 prey types (Fig. 1; Tab. 1). Flatworms (D. lugubris), leeches ( $G$. heteroclita), waterboatmen (Corixa sp.), damselfly nymphs (Calopteryx splendens) and nymphs of the casebuilding caddisfly (Potamophylax sp.) were not consumed. Consumption rates differed significantly between gammarid species (KruskalWallis ANOVA: $\left.\mathrm{H}=10.1_{(78)}, \mathrm{P}<0.01\right)$ with $D$. villosus showing the highest consumption rates (U-test: all Ps $<0.01$ ). Dikerogammarus villosus consumed all Tubifex worms, all $A$. aquaticus, all simuliid, chironomid and ephemerid larvae and approximately $1 / 3$ of Hydropsyche nymphs present in the experimental vessels (Fig. 1). Echinogammarus ischnus consumed more prey than the native species $G$. pulex and $G$. roeseli (U-test: Ps $<0.01$ ); no difference in consumption rate was observed between the two native species (U-test: $\mathrm{P}=\mathrm{ns}$ ).

In the mixed-prey experiments, chironomid larvae were eaten by all gammarid species (Fig. 2). Again, consumption rates varied between gammarid species (Kruskal-Wallis ANOVA: $\mathrm{H}=9.0_{(4)}, \mathrm{P}<0.05$ ) with $D$. villosus consuming more prey than the other species (Utest: Ps <0.05). No difference in consumption rate could be found beween the other gammarid species (U-test: Ps $=\mathrm{ns}$ ). However, E. ischnus and G. pulex consumed a broader prey spectrum than did $G$. roeseli which consumed only chironomid larvae. Hydropsyche larvae were not consumed in this experiment.

In the second single-prey experiment (experiment with high prey density), again, consumption rates differed between gammarid species (one-way ANOVA: A. aquaticus, $\mathrm{F}_{(3 / 39)}=25.0, \mathrm{P}<0.0001$; chironomid larvae, $\mathrm{F}_{(3 / 55)}=16.0, \mathrm{P}<0.0001$; Fig. 3). The invasive species $D$. villosus consumed a greater number of $A$. aquaticus and chironomid larvae than all other gammarid species (Tukey). Echinogammarus ischnus consumed the same number of $A$. aquaticus and chironomid larvae than $G$. pulex but a higher number than $G$. roeseli (Tukey). Gammarus pulex consumed a 


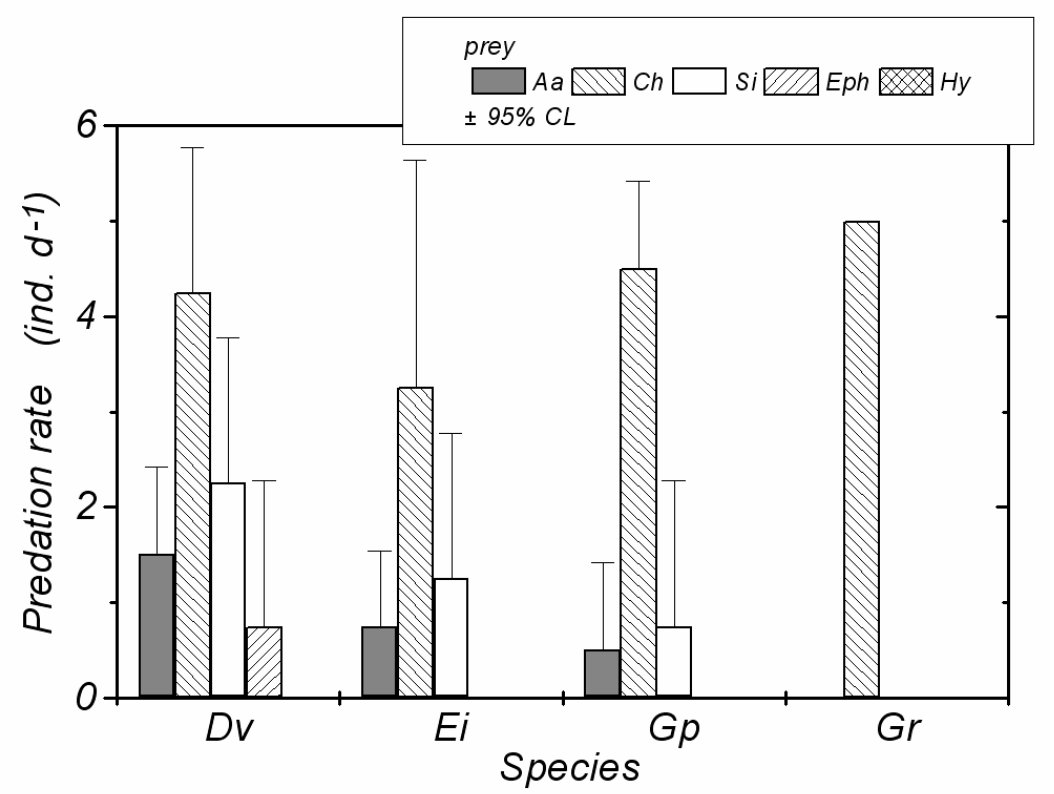

Fig. 2. Average number of macroinvertebrates $( \pm 95 \% \mathrm{CL})$ consumed by one adult invasive and native gammarid in mixed-prey experiments. Abbreviations see figure 1 .
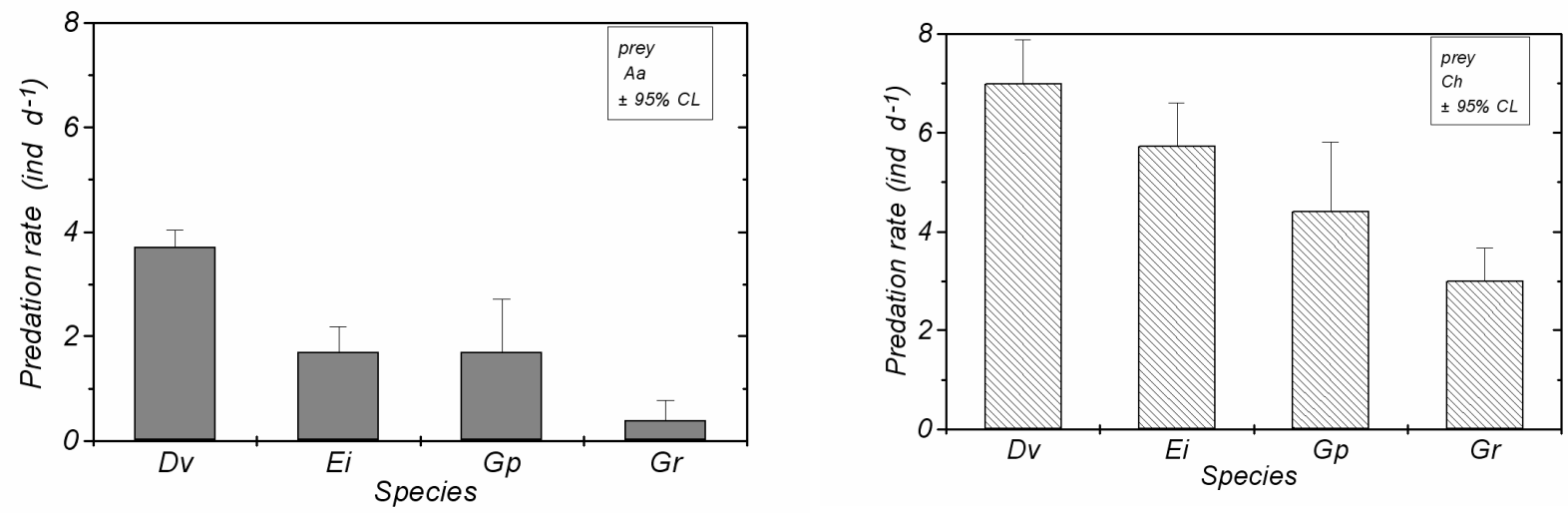

Fig. 3. Average number of macroinvertebrates $( \pm 95 \% \mathrm{CL})$ consumed by one adult invasive and native gammarid in single-prey experiments with high prey density. Abbreviations see figure 1 .

higher number of $A$. aquaticus than $G$. roeseli but the same number of chironomid larvae. Chironomid larvae were consumed at higher rate than A. aquaticus (Fig. 3). Biomasses of $A$. aquaticus and chironomid larvae, respectively, consumed per predator and day were 24 and $25 \mathrm{mg}$ (D. villosus), 11 and $20 \mathrm{mg}$ (E. ischnus), 11 and $17 \mathrm{mg}$ (G. pulex) and 2 and $11 \mathrm{mg}$ (G. roeseli).

\section{DISCUSSION}

Formerly, gammarids have been regarded as part of the "shredding" functional feeding group, consuming detritus, leaves and associated microbes (e.g. Friberg \& Jacobsen 1994; Gayte \& Fontvieille 1997). More recently, based on results of gut content analyses and predation experiments (Summers et al. 1996; Dick 1992, 1995; MacNeil et al. 1997; Dick \& Platvoet 1996, 2000; Dick et al. 2002; Kelly et al. 2002; Kinzler \& Maier 2003), gammarids are increasingly recognized as omnivores and predators consuming a wide array of prey organisms. Some invasive gammarids which are known to be strong predators (e.g. Dick \& Platvoet 2000, 2001; Dick et al. 2002; Kinzler \& Maier 2003) are expected to cause alterations in the macroinvertebrate community. Recently, Dick et al. (2002) studied the predatory impact of the invasive gammarid $D$. villosus and the native G. duebeni on an array of macroinvertebrates including leeches (Piscicola geometra L.), crustaceans (Eurycercus lamellatus O.F. MÜLLER, Neomysis integer LEACH, A. aquaticus), water insect 
larvae (Ischnura elegans VAN DER LINDE, Caenis robusta EATON, Chironomus sp., Chaoborus sp.) and adult water insects (Sigara sp.). They found that D. villosus fed on all prey species tested and that D. villosus consumed more prey than G. duebeni. Our results also show that $D$. villosus consumed more and a broader prey spectrum than the other gammarids (E. ischnus, $G$. pulex and $G$. roeseli) tested. That waterboatmen (Corixa sp.), damselfly nymphs (C. splendens) and leeches $(G$. heteroclita) were not consumed in our study while representatives of the same taxonomic groups were consumed in the study of Dick et al. (2002) may result from differences in experimental design and / or differences in prey species and sizes used between the two studies. Our results further suggest that predatory impact of the invasive $E$. ischnus on macroinvertebrates is somewhat higher than that of the native species $G$. pulex and that the native $G$. roeseli is the weakest predator of all gammarid species tested.

That chironomid larvae were most heavily preyed upon by all gammarids in the mixed prey experiments was expected because this prey is rather immobile and can easily be captured by gammarids. Dick et al. (2002) also found high predation of chironomid larvae in the presence of $D$. villosus or $G$. duebeni which coincides with our results. That, Hydropsyche larvae were less consumed may result from the fact that this caddisfly larva is able to defend itself with its pointed mandibles. Our results further show that gammarids can consume macroinvertebrate biomasses of 11 (G. roeseli) to $25 \mathrm{mg}$ (D. villosus) per day which is in the range of one third of their own biomass.

Our results do not prove that predation by invasive gammarids is a major cause for the decline of macroinvertebrate numbers in several Central European large rivers. Many other invasive species may interfere with natives by competition and modification of interspecific interactions. However, taking into account that density of gammarids may range from several hundreds to thousands per $\mathrm{m}^{2}$, the predatory habit of invasives may have contributed to some extend to the decrease of abundance in some macroinvertebrate taxa or support a role for invasive predation in decline of native macroinvertebrates.

\section{REFERENCES}

Callies, K. 1996. Zur Ernährungsökologie von Zerkleinerern in Fließgewässern, unter besonderer Berücksichtigung von Gammarus pulex L. (Amphipoda, Crustacea). Diploma Thesis in Biology, University of Kiel, Germany.

Devin, S., J.N. Beisel, V. Bachman \& J.C. Moreau. 2001. Dikerogammarus villosus (Amphipoda: Gammaridae): another invasive species newly established in the Moselle River and French hydrosystems. Annls. Limnol., 37: 21-27.

Dick, J.T.A. 1992. The nature and implications of differential predation between Gammarus pulex and G. duebeni celti- cus (Crustacea: Amphipoda). J. Zool., Lond., 227: 171183.

Dick, J.T.A. 1995. The cannibalistic behaviour of two Gammarus species (Crustacea: Amphipoda). J. Zool., Lond., 236: 697-706.

Dick, J.T.A. 1996. Post-invasion amphipod communities of Lough Neagh, Northern Ireland: influences of habitat selection and mutual predation. J. Anim. Ecol., 65: 756-767.

Dick, J.T.A. \& D. Platvoet. 1996. Intraguild predation and species exclusion in amphipods: the interaction of behaviour, physiology and environment. Freshwat. Biol., 36: 375-383.

Dick, J.T.A. \& D. Platvoet. 2000. Invading predatory crustacean Dikerogammarus villosus eliminates both native and exotic species. Proc. Roy. Soc. London, Series B, Biological Sciences, 267: 977-983.

Dick, J.T.A. \& D. Platvoet. 2001. Predicting future aquatic invaders; the case of Dikerogammarus villosus. Aquatic Nuisance Species, 4: 25-27.

Dick, J.T.A., D. Platvoet \& D.W. Kelly. 2002. Predatory impact of the freshwater invader Dikerogammarus villosus (Crustacea: Amphipoda). Can. J. Fish. Aquat. Sci., 59: 1078-1084.

Friberg, N. \& D. Jacobsen. 1994. Feeding plasticity of two detritivore-shredders. Freshwat. Biol., 32: 133-142.

Gayte, X. \& D. Fontvieille. 1997. Autochthonous vs allochthonous organic matter ingested by a macroinvertebrate in headwater streams: Gammarus as a biological probe. Arch. Hydrobiol., 140: 23-36.

Kelly, D.W., J.T.A. Dick \& W.I. Montgomery. 2002. Predation on mayfly nymph, Baetis rhodani, by native and introduced Gammarus: direct effects and the facilitation of predation by salmonids. Freshwat. Biol., 47: 1257-1268.

Kinzelbach, R. 1995. Neozoans in European waters - Exemplifying the worldwide process of invasion and species mixing. Experientia, 51: 526-538.

Kinzler, W. \& G. Maier. 2003. Asymmetry in mutual predation: possible reason for the replacement of native gammarids by invasives. Arch. Hydrobiol., 157: 473-481.

Kley, A. \& G. Maier. 2003. Life history characteristics of the invasive freshwater gammarids Dikerogammarus villosus and Echinogammarus ischnus in the River Main and the Main-Donau Canal. Arch. Hydrobiol., 156: 457-469.

MacNeil, C., J.T.A. Dick \& R.W. Elwood. 1997. The trophic ecology of freshwater Gammarus (Crustacea: Amphipoda); problems and perspectives concerning the functional feeding group concept. Biol. Rev., 72: 349-364.

Summers, R.B., M.D. Delong \& J.H. Thorp. 1996. Ontogenetic and temporal shifts in the diet of the amphipod Gammarus fasciatus in the Ohio River. Am. Midl. Nat., 137: 329-336.

Tittizer, T. 1996. Vorkommen und Ausbreitung aquatischer Neozoen (Makrozoobenthos) in den Bundeswasserstraßen. In: Gebhardt H, Kinzelbach R, Schmid-Fischer S (Eds), Gebietsfremde Tierarten. Ecomed Verlag, Landsberg: 4986.

Tittizer, T., F. Schöll, M. Banning, A. Haybach \& M. Schleuter. 2000. Aquatische Neozoen im Makrozoobenthos der Binnenwasserstraßen Deutschlands. Lauterbornia, 39: 1-72.

Van der Velde, G., S. Rajagopal, B. Kelleher, I.B. Musko \& A. bij de Vaate. 2000. Ecological impact of crustacean invaders: general consideration and examples from the Rhine River. In: Von Vaupel Klein, Schram (Eds), The biodiversity crisis and crustacean. Proceedings of the Fourth International Crustacean Congress. Crustacean Issues 12. Rotterdam, The Netherlands: 3-33. 